\title{
CHALLENGES AND SKILLS OF LEADERSHIP IN THE DEVELOPMENT OF A CULTURE OF INNOVATION: A LITERATURE REVIEW
}

\begin{abstract}
The construction of an innovation-oriented culture has been a goal in different organizations due to the need of remaining competitive. This consolidation depends, among other factors, on the commitment and performance of the leadership. This study aims to analyze the challenges and skills of leadership in the development of a culture of innovation. This is a literature review article, which was prepared using the narrative review technique. The main results suggest the importance of the conceptual and human skills of leaders in facing the challenges required for promotion of a culture of innovation.
\end{abstract}

Keywords: skills; leadership; culture of innovation.

\section{DESAFIOS E HABILIDADES DA LIDERANÇA NO DESENVOLVIMENTO DE UMA CULTURA DA INOVAÇÃO: UMA REVISÃO DA LITERATURA}

Resumo: A construção de uma cultura orientada à inovação tem sido meta em diferentes organizações em função da necessidade de se manter competitiva. Essa consolidação depende, dentre outros fatores, do comprometimento e da atuação da liderança. Este estudo tem como objetivo analisar os desafios e as habilidades da liderança no desenvolvimento de uma cultura de inovação. Trata-se de um artigo de revisão de literatura, que foi elaborado com o uso da técnica de revisão narrativa. Os principais resultados sugerem a importância das habilidades conceituais e humanas dos líderes para o enfrentamento dos desafios necessários na promoção de uma cultura de inovação.

Palavras-chave: habilidades; liderança; cultura de inovação. 


\section{INTRODUCTION}

Several researchers, based on the growing relevance of the innovation theme, have been studying which factors contribute or hinder its development in organizations $[1,2,3,4,5]$. Among these agents, organizational culture has been the subject of studies that seek to understand and confirm its relationship with the performance of innovation in different countries and ways to identify elements that promote its consolidation.

The culture of innovation can be developed and managed in organizations. Building and establishing management practices that promote innovation-oriented behaviors and environments, without losing focus on operational efficiency and expected results is a challenge for organizations. A survey carried out by the Innovation Leader, in 2017, with 270 world leaders, points out the culture in large companies as an inhibiting factor for innovation in the perspective of $45 \%$ of the sample respondents. According to the author, attempts to introduce changes and carry out experiments are generally treated with resistance [6].

In this construction, the performance of the leadership is the key to promote the desired change. Leadership can be understood as "a process whereby an individual influences a group of individuals to achieve a common goal" [7]. Leaders must take responsibility for defining new management behaviors and practices [2].

Leadership and management are different and complementary ways. Management involves planning, budgeting, organizing, controlling and solving problems, achieving order and predictability in the short term. Leadership involves establishing direction to align and motivate people to deal with change. Establishing direction is an inductive process of creating a long-term vision for a business, technology or corporate culture. This vision, when communicated in a clear and broad way, promotes alignment and empowers the followers. Managers seek the best fit between people and activities, while leaders seek the best fit between people and the vision. Organizations' competitiveness depends simultaneously on these two roles [8].

Therefore, the consolidation of a culture that supports performance and innovation depends, among other factors, on the performance of the leadership [8, 9, 10]. Considering the different factors surrounding the theme, this study aims to analyze the challenges and skills of leadership in the development of the culture of innovation through a literature review.

\section{METHODOLOGY}

This review article was written using the narrative review technique. The narrative review of the literature describes or discusses a certain theme, under the interpretation and critical analysis of the author, based on a broad search for bibliographic or electronic information, without necessarily detailing the criteria adopted for the selection and evaluation of works [11]. Indexed articles and publications were collected between May 2019 and May 2020, with the key words leadership and culture of innovation. 


\section{RESULTS AND DISCUSSION}

The results are presented and discussed in the following sequence: (a) leadership challenges; (b) leadership skills.

\subsection{Leadership challenges}

An organization's capacity to innovate is based on a system of choices and practices about people, processes, structures and behaviors managed by leaders [1]. However, before an internal competition for resources between new and existing businesses, leaders will naturally feel that the best option is to expand established business lines instead of investing in new areas not yet controlled [12].

Being able to position themselves aside their own culture to identify which aspects of the current culture must be preserved and which ones need to be modified is a central issue for leaders [13]. It is a difficult process that requires new ways of thinking, because it goes against the learned recipes for success [13]. The denial of the need for change occurs both when things are doing well and during difficult times, since keeping on investing in the formula and reinforcing the values that led to success generally seems to be more logical than questioning them [14].

The leader is responsible for promoting conditions to implement changes and reduce resistance, as each person perceives changes in a different way, which determines their action or reaction to the new [15]. At the highest level of the organization, leadership is responsible for processes related to innovation strategies: central themes, results goals and possible alliances. While at the most management and tactical level, they are responsible for unfolding the strategy through the generation of ideas, projects development, technology monitoring and definition of recognition and reward policies involved in the innovation processes [4]. Creating connections, building and managing knowledge through creative routines is the leader's role [16].

\subsection{Leadership skills}

Literature points out some important characteristics of leadership for the promotion of the culture of innovation. Tolerance to failure should not be understood as tolerance to incompetence; willingness to experiment requires great discipline to select experiments based on their learning value; psychological security must support both the act of criticizing and accepting criticism; collaboration should not be confused with consensus that can be detrimental to quick decision-making when dealing with complex problems; lack of hierarchy does not mean the absence of leadership, which must articulate strategic visions [1].

In this sense, leaders can review their performance in order to assume behaviors or execute practices that will favor the consolidation of a culture of innovation: clearly communicate the importance and what is expected from innovation $[17,18]$; promote openness to change and favor experimentation $[2,19]$; seek guidance for the external environment through social networks [20, 17, 19]; mitigate critical reactions and encourage the exploration of new ideas [2, 19]; ask for and listen carefully to the followers' contributions [17]; measure and reward innovation [2, 17, 21, 22]; challenge employees to constantly improve products and processes by taking 
risks [2, 17, 23]; provide support for group work [14, 23]; encourage the exchange of knowledge, including that obtained from errors and failures [2, 19, 24]; tolerate failure considering it as a search for new opportunities [2, 19, 24]; publicize the positive contributions of employees [2, 21]; promote a conception of error as a learning opportunity [4]; encourage employee training [2, 22] and take advantage of the knowledge and skills of those with more seniority and experience [2].

Leaders must continually find out when they should dedicate time: compromising and valuing individuality, making efforts to understand and transcending dominant currents and work habits, freeing up the flow of information while recognizing the importance of communicating in an authentic and realistic way, making their employees better, establish a broader purpose than the vision and mission in order to create and maintain powerful connections between personal and organizational values, show how daily work makes sense by assessing motivation and involvement in the tasks performed and establish rules in which people can believe, understanding that systematization does not need to lead to bureaucracy [25].

The development of a culture of innovation, a phenomenon of social interaction where learning occurs through shared events and results [27], depends essentially on the skills of leaders. Leadership literature indicates three classes of skills: technical, conceptual and human [26]. Human skill refers to the ability of working in groups and building cooperative relationships, and conceptual skill is related to the development of a systemic view of the company. Both are the most demanded at the highest levels of organizations at the expense of technical skills (specialized and instrumental knowledge for carrying out professional activity) [26]. Figure 1 shows the importance of these skills in the leadership performance.

Figure 1. Relative importance of skills at different levels.

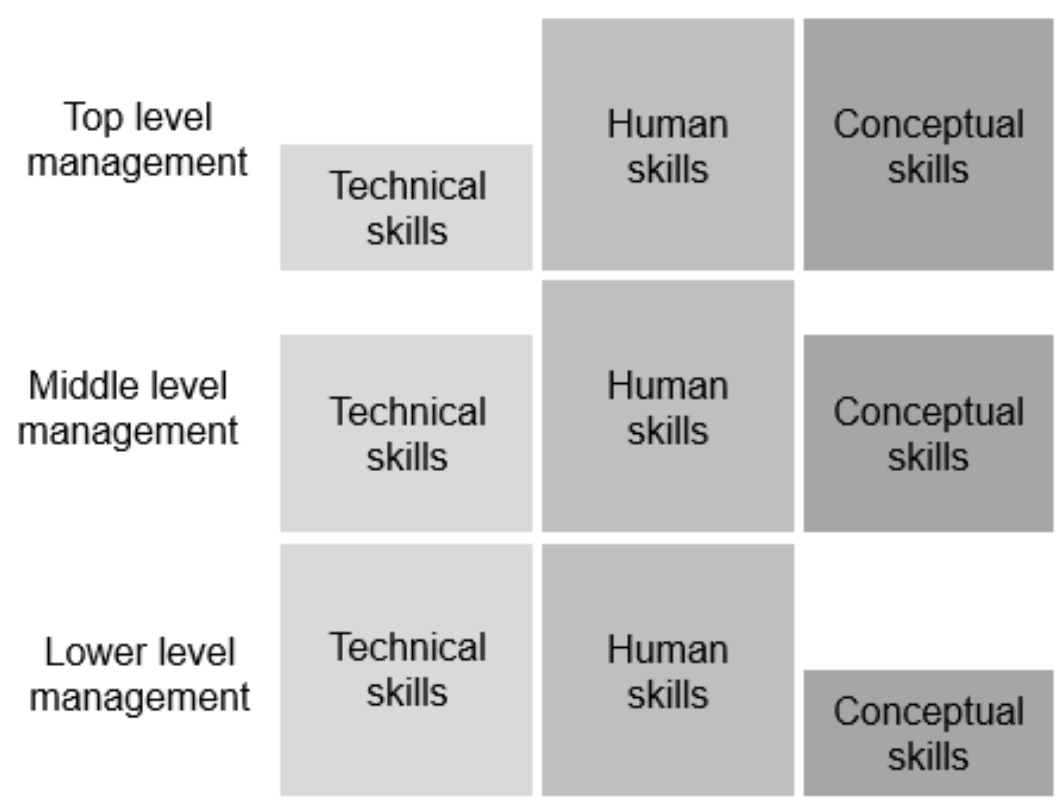

Source: Adapted from [26]. 
Table 1 presents the main skills of the leader required for promoting a culture of innovation, as identified in the literature review, and according to the classification of technical, human and conceptual skills.

Table 1. Main leadership skills required for promoting a culture of innovation, as identified in the literature review.

\begin{tabular}{|c|c|}
\hline $\begin{array}{l}\text { Conceptual } \\
\text { skills }\end{array}$ & 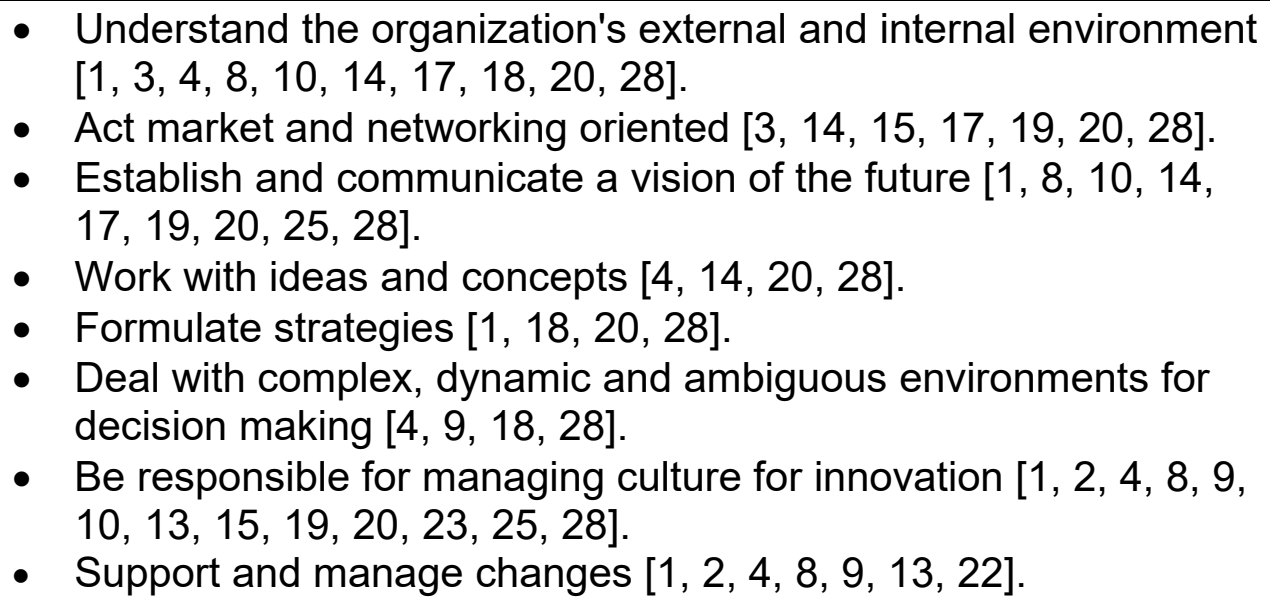 \\
\hline $\begin{array}{c}\text { Human } \\
\text { skills }\end{array}$ & 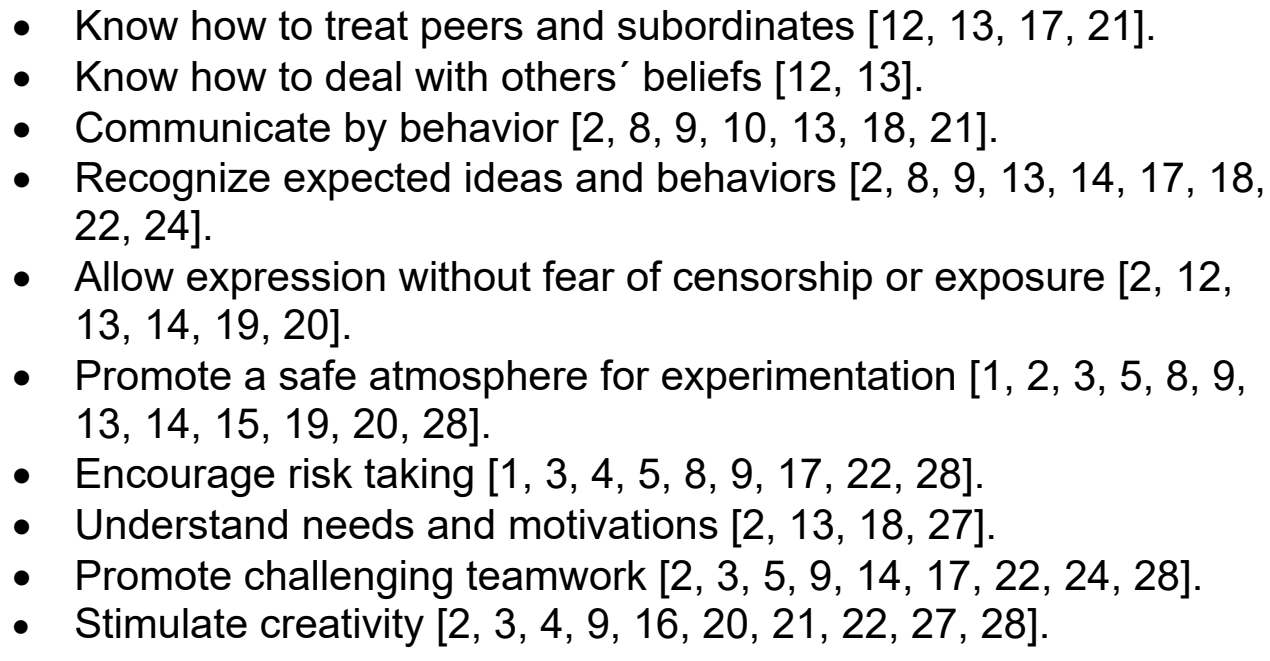 \\
\hline $\begin{array}{l}\text { Technical } \\
\text { skills }\end{array}$ & $\begin{array}{l}\text { - Specific and specialized knowledge through the mastery of } \\
\text { techniques and tools }[2,4,10,18,20,28] \text {. } \\
\text { - } \quad \text { Innovation and project management }[3,4,8,21,22,28] \text {. } \\
\text { - } \text { Knowledge management }[2,4,8,10,13,16,21,27,28] \text {. }\end{array}$ \\
\hline
\end{tabular}

Source: Created by the Author.

Leaders of top and middle level management, with greater responsibility for the development of innovations and competitiveness, must recognize and understand the importance of developing conceptual and human skills, assuming responsibility and favoring the emergence of new purposes, values and more adherent beliefs to an innovation-oriented culture. 


\section{CONCLUSION}

This study has analyzed the challenges faced by leadership and the skills required for promotion of a culture of innovation, identifying the importance of conceptual and human skills to face the challenges. As it could be seen, the construction of a culture of innovation fundamentally depends on the performance of the leadership and should not be seen as a short-term goal. Leaders must be aware of the factors that determine this new culture and seek the development of new skills and practices that favor new behaviors, values and beliefs oriented towards innovation.

Considering the study's limitations, it is suggested that further research expand the literature search in different databases and the categories of analysis through a systematic review.

\section{REFERENCES}

${ }^{1}$ PISANO, Gary P. Creative Construction: The DNA of Sustained Innovation. Public Affairs, 2019.

2 VILTARD, Leandro Adolfo; ACEBO, Mario N. Corporate Culture: a key to stimulate innovation. Independent Journal of Management \& Production, v. 9, n. 3, p. 869888, 2018.

${ }^{3}$ DUTRA, Frederico Giffoni; ALMEIDA, Fernanda Gomes. Elementos para estímulo da cultura de inovação: mapeamento das diretrizes adotadas por empresas de destaque brasileiras. Revista Brasileira de Gestão e Inovação, v. 5, n. 3, p. 95-120, 2018

4 TERRA, José Cláudio. 10 dimensões da gestão da inovação: Uma abordagem para a transformação organizacional. São Paulo: Elsevier, 2012.

${ }^{5}$ GODOY, Renata Semensato Pereira de; PEÇANHA, Dóris Lieth Nunes. Cultura organizacional e processos de inovação: um estudo psicossociológico em empresa de base tecnológica. Boletim-Academia Paulista de Psicologia, v. 29, n. 1, p. 142163, 2009.

${ }^{6}$ KIRSNER, Scott. Os maiores obstáculos para a inovação em grandes empresas. Harvard Bussiness Review, 2018. Disponível em: https://hbrbr.uol.com.br/obstaculos-inovacao/ . Acesso em: 14/05/2019.

7 NORTHOUSE, Peter G. Leadership: theory and practice. 7ed. California: SAGE, 2016. 
${ }^{8}$ HESKETT, James L.; KOTTER, John P. Cultura Corporativa e o Desempenho Empresarial. São Paulo: Makron Books, 1994.

${ }^{9}$ AHMED, Pervaiz K. Culture and climate for innovation. European journal of innovation management, v. 1, n. 1, p. 30-43, 1998

10 GROYSBERG, Boris et al. The leader's guide to corporate culture. Harvard Business Review, v. 96, n. 1, p. 44-52, 2018.

${ }^{11}$ ROTHER, Edna Terezinha. Revisão sistemática X revisão narrativa. Acta Paulista de Enfermagem, São Paulo, v. 20, n. 2, p.v-vi, abr./jun. 2007.

12 WLADAWSKY-BERGER, Irving. Honest Conversations - The Key to a Winning Transformational Strategy. Disponível em: https://blog.irvingwb.com/blog/2020/02/honest-conversations-the-key-to-a-winningstrategy.html . Acesso em: 04/04/2020.

${ }^{13}$ SCHEIN, Edgar H. Organizational culture and leadership. John Wiley \& Sons, 2004.

14 EUCHNER, Jim. Building a Culture of Innovation. Research Technology Management, v. 59, n. 6, p. 10-11, 2016.

${ }^{15}$ DÁVALOS, Raúl Marcelo Ferrer. La influencia del factor humano, el liderazgo y la cultura de las organizaciones en los procesos de implementación y gestión del cambio organizacional. Revista Internacional de Investigación en Ciencias Sociales, v. 11, n. 1, p. 102-114, 2015.

${ }^{16}$ NONAKA, Ikujiro; TOYAMA, Ryoko. A firm as a dialectical being: towards a dynamic theory of a firm. Industrial and Corporate change, v. 11, n. 5, p. 995-1009, 2002.

${ }^{17}$ SOKEN, Nelson H.; BARNES, B. Kim. What kills innovation? Your role as a leader in supporting an innovative culture. Industrial and Commercial Training, 2014.

${ }^{18}$ HARTMANN, Andreas. The role of organizational culture in motivating innovative behaviour in construction firms. Construction innovation, v. 6, n. 3, p. 159-172, 2006.

19 HUTCHINSON, Karise. Leadership purpose. In Leadership and small business. London, UK: Palgrave Macmillan, 2018. 
${ }^{20}$ DOBNI, C. Brooke. Measuring innovation culture in organizations: The development of a generalized innovation culture construct using exploratory factor analysis. European Journal of Innovation Management, v. 11, n. 4, p. 539-559, 2008.

${ }^{21}$ HOGAN, Suellen J.; COOTE, Leonard V. Organizational culture, innovation, and performance: A test of Schein's model. Journal of Business Research, v. 67, n. 8, p. 1609-1621, 2014.

${ }^{22}$ AITHAL, Rajesh K. Book essay on Unrelenting Innovation: How to create a culture for market dominance. Journal of Business Research, v. 68, n. 2, p. 322-325, 2015.

${ }^{23}$ NARANJO-VALENCIA, Julia C.; CALDERON-HERNÁNDEZ, Gregorio. Model of Culture for Innovation. In: Organizational Culture. IntechOpen, 2018.

${ }^{24}$ DODGE, Richard et al. The Role of Leadership in Innovation: A quantitative analysis of a large data set examines the relationship between organizational culture, leadership behaviors, and innovativeness. Research Technology Management, v. 60 , n. 3, p. 22-29, 2017.

${ }^{25}$ GOFFEE, Rob; JONES, Gareth. Creating the best workplace on earth. Harvard Business Review, v. 91, n. 5, p. 98-106, 150, 2013.

${ }^{26}$ KATZ, Robert L. Skills of an effective administrator. Harvard Business Review, 1974. Disponível em: https://hbr.org/1974/09/skills-of-an-effective-administrator. Acesso em: 28/05/2020.

${ }^{27}$ REVILLA, Elena. O dilema da criatividade. RAE-Revista de Administração de Empresas, v. 59, n. 2, p. 149-153, 2019.

${ }^{28}$ TIDD, J.; BESSANT, J.; PAVITT, K. Gestão da inovação. 3ed. São Paulo: Artmed, 2008. 